\title{
Der ordene mangler. Tre selvskadere forteller
}

Av Arne Thorvik

\section{I denne artikkelen presenteres tre intervjuer med mennesker som har egenerfaring med selvskading.}

«HVA GJØR DEN ARME NÅ? HAN FALT VEL LITT TIL RO?» spør korlederen i Sofokles' drama Kong Ødipus. Forut for dette har Đdipus skadet seg selv til blinde, etter at psykisk smerte og bitter erkjennelse hadde tatt overhånd hos ham.

Selvskading er ikke noe nytt fenomen. I en tidligere artikkel i Suicidologi er det vist at fenomenet kunne opptre i antikken og middelalderen som en del av kulturelle eller religiøse ritualer. Siden 180o-tallet er selvskading mer sett som uttrykk for en medisinsk problematikk (Mellesdal, 2018). En psykodynamisk orientert forfatter vektla i mellomkrigstiden behovet for selvstraff ved det han kalte «self-harm» (Menninger, 1938). 
Tidligere har medisinske lærebøker for det meste omtalt selvskading som psykotisk motivert, eller relatert til en autistisk tilstand. Kasuistisk har man også kunnet vise til at selvskading kan gi fordeler (såkalt sekundærgevinst). Et eksempel er fengselsinnsatte som skadet seg (ofte i form av svelging av metallgienstander), og dermed ble brakt fra fengselet til et foretrukket sykehusopphold. Denne forståelsen er likevel for snever (Bhugra \& Munro, 1997).

De senere tiårene har det vært økende interesse og fokus på selvskading som selvstendig fenomen, ikke som relatert til kjent psykisk lidelse eller åpenbar sekundærgevinst. Et stort antall bøker og artikler har belyst dette, både fra et faglig ståsted og fra et brukerperspektiv.

Selv om definisjonene har variert noe, er det enighet om at selvskading er kvalitativt annerledes enn selvmord og selvmordsforsøk. De to sistnevnte er definert som en handling som personen intenderte skulle føre til døden. Også selvskading er en villet handling, men uten intensjon om å dø (selv om det kan skje at handlingen utilsiktet blir fatal og resulterer i død).

I egopsykologisk tradisjon har fenomenet vært vurdert som et forsøk på mestring av psykisk smerte og livets påkjenninger.

\section{Materiale og metode}

I denne artikkelen presenteres tre intervjuer med mennesker som har egenerfaring med selvskading. Interviuobjektene var rekruttert via dette tidsskriftet, og hadde sagt seg villige til å delta.

Hvert av intervjuobjektene (kalt informantene) fikk tilsendt et semistrukturert intervju, som ble besvart skriftlig.

I ettertid har artikkelforfatteren laget sammendrag av de tre interviuene, som giengis nedenfor. Informantene har fått lese igiennom sammendraget, for kommentar og korreksion. Opplysninger som hypotetisk kunne bidra til gienkjennbarhet, er fjernet.

Norsk samfunnsvitenskapelig datatieneste (NSD), personvernombudet ved Sykehuset i Vestfold (der artikkelforfatteren er ansatt) ble orientert, videre personvernombudet og utøver av behandlingsansvaret ved Universitetet i Oslo (sistnevnte en instans som følger opp etterlevelsen av personregelverket ved universitetet giennom juridisk rådgivning, internkontroll, avvikshåndtering og opplæring).

Med basis i den filosofiske retningen som kalles fenomenologi, har målsetningen vært å innta informantenes perspektiv, og se selvskadingens dynamikk fra deres ståsted. 
Intervjuene

\section{Informant $A$}

Informant A (kvinne i 30-årene) har erfaring med selvskading siden ungdommen. «Da gikk jeg fra «metode» til «metode». Jeg tenker i dag at det handlet om å fungere. Få ting til å gå rundt. Følelsesregulering.»

A beskriver selvskading som et middel for å unngå å kjenne på smerten som lå i henne, «klare å leve i et hjem som ikke fungerte».

Som ung drev hun idrett, og måtte velge selvskadingsmetoder som ikke viste skadet hud. Etter hvert ble det vanskeligere å skjule selvskadingen. Hun nevner en episode på jobb der hun begynte å gråte, så skadet seg med kniv for tilsynelatende å kunne fungere. «Slik holdt jeg på ofte under bordet i møter. Gjemte at jeg skadet meg selv for å være til stede i ulike situasjoner.»

Interessant nok nevner $\mathrm{A}$ at hun brukte hardtrening innen idrett for å dekke samme behov. Hun trente $4-5$ timer om dagen. «Idretten hadde mye positivt i seg, men det var også den ultimate måten å rømme fra hvordan jeg hadde det. Ikke føle. Bryte meg selv ned.»

Selvskading ble den eneste måten hun kjente til for å fungere. Etter hvert ble det som en avhengighet. Og noen ganger et forsøk på å si ifra om hvor vanskelig hun hadde det.

Responsen var alltid den samme - «stillhet eller tilsnakk». «Skjerp deg», «tenk positivt», «du er jo så flink», «du har ingenting å være trist for», «det hjelper ikke å sutre».

For A ble det da en løsning å bli mer utspekulert overfor seg selv, bytte strategier. «Risping er jo ikke alvorlig». "Samtidig klarte jeg i stadig støre grad begrave hva jeg følte for meg selv. Etter hvert ble ikke prosiektet å skjule for andre hvordan jeg hadde det, men for meg selv. Det skulle ta veldig mange år med terapi før jeg fikk tilgang til egne følelser».

I møte med helsevesenet opplevde hun tidlig at «sånn giør man ikke», eventuelt at man prøvde å skremme henne med at «arr er stygt». Konsekvensen var at As selvskading tok mer skjulte former.

Hun nevner en episode der hun hadde delt en penn i to og spisset den som en kniv. «Min kontakt

Det man ikke bor giore, er å legge skam på fenomenet, eller være bastant på hvorfor en selvskader, «bruke diskurs som: ta deg sammen, det er ikke så alvorlig, og så videre». den dagen bare gikk. Tittet innom innimellom, men sa ikke et ord. Dette var ikke noe jeg ville dødd av. Likevel, inni meg, var en plan om å kutte pulsåren for å dø». Nettopp dette opplevde A som smertefullt, at ingen tok det alvorlig. «Teg hadde ikke trengt å bli dullet med i det øyeblikket. Men noen få ord kunne giort all verdens forskjell. Bare ved å si noe som at: «Jeg ser du har det vondt. Om du ønsker å prate om det, er jeg tilgiengelig (...). Istedenfor satt jeg alene, og fikk nok en gang «bekreftet» at jeg ikke var verdt noen tid og at min smerte ikke er alvorlig nok.»

Etter hvert startet A i langvarig mentaliseringsbasert (MBT) gruppe- og individualterapi. «Det som var mest nyttig, som jeg har tatt med meg videre, har vært å lære mer om meg selv og andre. I første omgang dreide mye seg om å klare finne alternative strategier for selvskading». A beskriver hvordan triggerne som tidligere fikk i gang selvskading nå er nesten ikkeeksisterende. «De ekstreme følelsesmessige reaksjonene på andre dukker ikke lenger opp. Helt automatisk dukker det opp en fargepalett for å forstå andre på veldig mange flere måter». Hun har lært seg ikke å ta tanker og følelser som dukker opp så alvorlig. «Gå en tur om følelser tar overhånd».

A peker på at behandling av selvskading må være individuelt tilpasset. Hun ser det som enormt viktig at man ikke har overdreven tro på en enkelt strategi, og undergraver alle andre. Likevel finner hun noen fellesnevnere: «Det å bli tryggere i seg selv, vite hvem man er, hva man står for og ha en retning i livet. Samtidig kunne etablere trygge relasjoner med andre, er noe jeg føler har gitt en grunnleggende endring for hvordan jeg fungerer i livet.»

Det man ikke bør giøre, er å legge skam på fenomenet, eller være bastant på hvorfor en selvskader, «bruke diskurs som: ta deg sammen, det er ikke så alvorlig, og så videre».

Når det gielder åpenhet om selvskading, i medier og skole, formidler A en ambivalens: «Både ja og nei. Noen ganger kan det bli mer av det man fokuserer på. Det er også slik at en kan trigges til å sette i gang. Jeg er nok fan av at vi snakker mer om det underliggende for selvskading. Hvilken funksjon det har.»

A opplever at brukererfaring blir utnyttet i stadig større grad. Likevel savner hun en støre bredde blant brukere, et helhetsbilde: «Fra brukere som har blitt avvist år etter år, til brukere har fått adekvat hjelp, og til de som har fått fantastisk hielp. Alle stemmer er like viktige.» 


\section{Informant $B$}

Informant B (kvinne i 30-årene) beskriver at hun begynte å skade seg i 17-årsalder. Det startet med forsiktig risping i låret. $\mathrm{B}$ ser dette i sammenheng med at hun hadde utviklet en spiseforstyrrelse. «Alle kunne se at jeg hadde «mistet kontrollen og blitt tykk, jeg trengte noe som var bare mitt, noe ingen visste om og som jeg kunne ha kontroll på selv.»

Også B beskriver selvskading som en type følelsesregulering, knyttet til en basal opplevelse av tomhet og uro. "Det var mye distraksjon i den fysiske smerten. (...) Å kutte meg har vært en måte å opprette kontakt med meg selv på, å kjenne at jeg var der, å kjenne noe. (...) Å kutte meg ga meg en ro, jeg kunne slappe av etterpå, og denne varte iallfall i noen timer, ofte i et par dager».

Selvskading ble også en slags synliggiøring for B av at hun hadde det vondt, liksom rettferdiggiorde at hun ikke gikk på jobb.

Interessant nok nevner B at selvskading kan ses på som et ønske om kommunikasjon: «Fordi det var så vanskelig å snakke, sette ord på, be om hjelp, henvende seg til andre, så var selvskadingen også språk, et språk der ordene manglet.»

\section{I behandlingen må man lete etter personens egen motivasion. Nettopp denne individuelle brukererfaringen kan utnyttes bedre i selve terapien.}

I møtet med helsevesenet var «et kutt noe veldig konkret, jeg har det vondt, se her», et dypt kutt som trenger å bli sydd - en konkret grunn til å komme. Selvskadingen muliggiorde å be om hielp. Det var ikke oppmerksomhet jeg søkte, jeg søkte hjelp og omsorg, som jeg trengte, jeg ba om det på den eneste måten jeg klarte å be om det på. Noen ganger var det bedre for meg å få sydd masse sting enn å bli sittende alene og ensom hjemme».

Hun forteller at selvskading kunne ha en funksion i perioder da bulimi var ekstrem, og at det bidro til at hun fortsatte med kutting. «Det var noe lettende i å finne noe som gjorde at jeg ikke trengte å spise og kaste opp like mye som jeg da hadde giort en stund.»

Når det gjaldt møtet med legevakten, har $\mathrm{B}$ i hovedsak gode erfaringer. "Siden 2011 har det vært mange møter, og aldri en virkelig kip opplevelse. Eller, jo, ett møte med en lege, men det varte i to minutter før sykepleier grep inn og fant en annen». På et helsefaglig studium noen år senere ble selvskading noen ganger tematisert. Hun opplevde også der å bli møtt med respekt og interesse, mye takket være enkelte lærere.

B forteller at hun fikk kontakt med barne- og ungdomspsykiatri da hun var tenåring, grunnet spiseforstyrrelse. Hun har hatt flere behandlingsløp, både individuelt og i grupper. Hun opplevde mentaliseringsbasert terapi (MBT) som nyttig. Selvskading må ikke få for mye fokus i seg selv. Tvert om ser hun det som viktig at behandlere «har tålt at selvskading har vært der og likevel hatt fokus på andre ting».

I behandlingen må man lete etter personens egen motivasjon. Nettopp denne individuelle brukererfaringen kan utnyttes bedre i selve terapien. Når det gielder åpenhet om fenomenet, er B litt ambivalent: «Kan sette i gang ideer, trigge. Ta det opp der det er et problem, allerede har oppstått, ikke overse. For eksempel i en ungdomsskoleklasse med flere som kutter seg og det tydelig smitter. Men, tror jeg, det er ikke hensiktsmessig at ungdom snakker spiseforstyrrelser og selvskading som del av undervisning for «å lære om»; bedre da å snakke om følelser og relasjoner».

Avslutningsvis nevner $\mathrm{B}$ at det kan være $\mathrm{i}$ overkant enkelt å tenke behandling av selvskading alene, man må være opptatt av det bakenforliggende. «Noen ganger er det «bare» selvskading, men dersom ikke - viktig å ta tak i selvskadingen og alt det andre.» 


\section{Informant $\mathrm{C}$}

Informant C (mann i 40-årene) beskriver omtrent 25 års erfaring med selvskading.

«Min selvskading har alltid vært en personlig ting, det har aldri vært et onske fra meg at verden skal kunne se mine arr og min smerte». Samtidig er det her en dualitet. Også C nevner at selvskading har kunnet fungere som et språk, «min måte å kommunisere at jeg hadde det vondt og var syk, var ved å skjære meg».

Likeledes beskriver også C selvskading som en type følelsesregulering, som kan «dempe det trykket og kaoset jeg har innvendig (...) jeg kan se på sårene/blodet, og på en forskrudd måte akseptere den situasjonen og sykdommen jeg befinner meg i.

$C$ nevner en periode der han slet voldsomt psykisk, men greide å fungere på jobb ved å skjære seg på toalettet, for deretter bandasjere kuttet og gå tilbake til arbeidet. Blodet og såret hadde en slags beroligende funksion. «leg klarte å bruke smerten til å holde fokus og roe ned tankene en stund.» Etter hvert ble dette «et innarbeidet handlingsmønster som ble tatt frem i motgang», og som giorde at han fortsatte med selvskading.

Helsevesenet har han blandede erfaringer med. Han nevner leger som har «gitt kjeft og uttrykt at de har bedre ting å giøre enn å lappe sammen slike som meg, før de vasker kuttene med et middel som svir som $\mathrm{F}$ og syr deg uten bedøvelse». Ved en anledning ble han brakt til legevakt av politi. «Og før legen kom inn og gjør det leger giør best, være drittsekk mot selvskadere, så pekket den ene politimannen borti leggen min med våpenet og spurte om jeg skiærte meg på bena og hvorfor jeg giorde noe så dumt.» - Likevel har han også positive opplevelser. «Når det gielder sykepleiere og da spesielt de i psykiatrien så stiller de i en klasse for seg, de fleste. For istedenfor å bli hysteriske når jeg kommer til de med kuttene eller stikkene, så spør de rolig og pent om hva jeg trenger av sårpleieprodukter, og så sier de at jeg må si ifra om jeg trenger hjelp».

$\mathrm{C}$ har aldri fått noen spesifikk behandling for selvskading, men behandlere har formidlet at «det å ha noe å skade seg på kan ha en større funksion enn om de skulle ha tatt fra meg muligheten». Uten selvskading kunne en allerede eskalert situasjon ha eskalert ytterligere. Selvskading er en mulighet for en viss kontroll, og et kommunikasjonsverktøy. Man kan ikke tvinge noen til å slutte med selvskading, det er en avgiørelse den enkelte må ta. «Man må legge mye av ansvaret på
Selvskading er en mulighet for en viss kontroll, og et kommunikasjonsverktøy. Man kan ikke tvinge noen til å slutte med selvskading, det er en avgiørelse den enkelte må ta.

selvskaderen, bare på den måten kan de oppnå en bevisstgiøring rundt det som giør at de skader seg.»

Behandlere bør aldri si til en selvskader at «man vet hvordan de har det». For det giør de ikke, det er det kun selvskaderen som vet. C oppfordrer til at samtaler bør dreies i retning av hva man ønsket å oppnå og tankene og følelsene som var til stede, ikke på selve handlingen eller sårene.

Også C er noe ambivalent til mer åpenhet om selvskading, nevner at det har vært bølger av selvskading i etterkant av filmer som har tatt opp fenomenet. Skal man omtale dette i skolen, bør det være på en måte som presenterer dynamikken og bakgrunnen. «Men i bunn og grunn så må selvskading opp i lyset, da det fortsatt er en altfor stor skam knyttet til det.»

Brukererfaringer blir ikke godt nok utnyttet, mener C. Videre tenker han seg at selvskading er mer enn at et individ kutter eller skjærer seg selv, det finnes også et annet nivå: «Jeg er redd for at mange av voldsepisoder og drap, både familiært og mot ukjente, kan være en form for selvskading, der de istedenfor å skade seg selv direkte giør det indirekte ved å skade andre, for deretter igien å oppnå en slags kraftig psykisk selvskading.» 


\section{Diskusjon}

Denne artikkelen er å forstå som en begrenset kvalitativ undersøkelse. Vitenskapsteoretikere har påpekt at forskning handler om å finne underliggende strukturer, utover enkeltbeskrivelser eller kasuistikker (Kuhn, 2012; 1962). Tre informanter er ikke et tilstrekkelig antall for å kunne postulere fellestrekk som måtte være ved fenomenet selvskading.

Når det er sagt, er det likevel mulig å påpeke noen fellestrekk ved de tre interviuene:

Alle tre informanter forteller om selvskading som en type følelsesregulering, noe man giør for å kunne fungere i hverdagen. Det ligger en distraksjon og paradoksal lindring ved at den psykiske smerten giøres fysisk. To av informantene beskriver selvskadingen som et språk, et ønske om kommunikasjon. Man kan også ane at de der og da har kient en tilgrunnliggende ensomhet.

For alle de tre informantene var selvskading et innarbeidet handlingsmonster eller en kjent, destruktiv mestringsstrategi i vanskelige perioder av livet, og relatert til en bakenforliggende tilstand.

Opplevelsen av møtet med helsevesenet er ulik, og to av informantene har overveiende gode erfaringer. Likevel husker alle et møte der fenomenet ble sett på moralsk, som et uttrykk for at informanten hadde feilet og burde «ta seg sammen».

De er positive til at brukererfaringer utnyttes, men ambivalente til mer åpenhet om fenomenet i media og undervisning.

Alle tre vektlegger at selvskading er et individuelt fenomen, med en individuell dynamikk. Helsearbeidere bør være varsomme med å formidle til en selvskader at man «forstår hvorfor». I den grad det går an å forstå fenomenet, krever det en forsiktig tilnærming til vedkommende over tid.

Dette er i så fall i samsvar med et moderne vitenskapsteoretisk fokus på «personalized medicine» (Solomon, 2015).

\section{Avslutning}

Filosofen Arthur Schopenhauer påpekte på 180o-tallet at det ligger noe paradoksalt livsbejaende i suicidalitet: Selvmorderen har hatt forventninger til tilværelsen som ikke er innfridd.

På samme måte kan selvskading ses som et fortvilet onske om mestring, og om livet.

Den chilenske poeten Raul Zurita (f. 1950) er nylig oversatt til norsk (Zurita, 2020). I et dikt beskriver Zurita hvordan han etter en opprivende hendelse kom til å brennemerke seg selv. Han gis siste ord:

Jeg ødela mitt forferdelige ansikt

Foran speilet

Ieg elsker deg - sa jeg til meg selv - jeg elsker deg

Ieg elsker deg høyere enn noe annet i verden

\section{REFERANSER}

Bhugra, D. \& Munro, A. (eds). (1997). Troublesome disguises: Underdiagnosed psychiatric disorders. Oxford: Blackwell Science.

Kuhn, T. (2012/1962). The Structure of scientific revolutions. University of Chicago Press.

Mellesdal, L. (2018). Beskrivelser, forståelse og definisjoner av selvskading fra antikken til i dag. Suicidologi: 23(2), 30-37.

Menninger, K. (1938). Man against himself. New York: Harcourt Brace Jovanovich.

Solomon, M. (2015). Making Medical Knowledge. Oxford University Press.

Zurita, R. (2020). Skjærsild. Oslo: Kolon (Gyldendal). 